\title{
Mitigation or missiles
}

\author{
The United States has the responsibly to not only protect its own citizens from the expected impacts of \\ climate change, but also people living in distant lands.
}

The release of the third US National Climate Assessment (NCA; www.globalchange.gov/) by the Whitehouse in May should give the people of America a lot to think about. According to the report, climate change is already affecting many of them in far-reaching ways. And things are expected to get a lot worse as climate change really sinks its teeth in, leaving no sector unscathed - health and wellbeing, water resources, infrastructure, industry, agriculture, ecosystems and the ecological services they provide, ocean resources (including fisheries) - you name it.

The NCA is the work of 300 experts from a variety of disciplines and is guided by a 60-strong advisory committee chaired by Jerry Melillo of Ecosystems Center, based at the Marine Biological Laboratory in Woods Hole, Massachusetts, USA. The report notes that there has been a detectable increase in US average temperature since 1895, when record keeping began; much of this increase has occurred since about 1970. It also makes clear that human activities - especially the burning of fossil fuels for energy - are influencing climate in unprecedented ways. Extreme weather events, such as destructive storms and droughts, are predicted to increase in frequency and severity as a consequence of the global warming to which we are already committed due to the levels of greenhouse gases (GHGs) currently in the atmosphere. How the impacts of climate change are now showing up throughout the nation is also amply documented in the assessment.

None of this will come as a surprise to scientists, many of whom have been warning for years of the reality of anthropogenic climate change and the risks associated with it. But will the average person on the street listen and take heed? Possibly - there are indications that a significant proportion of US citizens now accept that climate change is happening, that it is caused by human activities and that it is potentially dangerous. But others, it seems, would rather accept the comforting reassurances of TV weather presenters (many of whom remain sceptical about global warming) than follow the science (Goldenberg, S. The Guardian; 6 May 2014; http://go.nature.com/lgQXud). It is clear that a lot of work still needs to be done to build public support for action on climate change, not least through communication and education. The NCA should help in this regard as it is accessible, interactive and readily understandable. Both young people and adults should be encouraged to read it.

The NCA rightly highlights the vulnerability of the sick and the poor - the US has no shortage of either - as well as children and the elderly, and the inadequacy of current climate change mitigation and adaptation measures, which are needed to avoid social, environmental and economic damage. Its release comes close on the heels of the Working Group III's contribution to the IPCC's Fifth Assessment Report (AR5 WG3), which considers all aspects of climate change mitigation, including its scientific underpinning, societal implications and opportunities for technological innovation aimed at reducing GHGs. The WG3 authors rightly emphasize the view that sustainable development in poorer nations, and the eradication of poverty itself, depends on effective action on climate. However, they also caution that development pathways must be carefully designed to minimize, or altogether avoid, any potentially damaging side-effects of mitigation measures. As the AR5 WG3 report puts it in its summary for policy makers, "Some mitigation policies raise the prices of some energy services and could hamper the ability of societies to expand access to modern energy services to underserved populations. These potential adverse side-effects can be avoided with the adoption of complementary policies." Partly for this reason, no doubt, the authors impress on the reader the importance of collective action and international collaboration on a global scale. Certainly, it is crucial that developing countries benefit from knowledge and technology transfer - economically and in terms of improvements in the quality of the environment, better health and more dependable food and water resources.

The greatest responsibility to act effectively and decisively on climate change surely falls squarely on the shoulders of those wealthy, developed nations whose profligate over-exploitation of natural resources characterized the nineteenth and twentieth centuries, and continues to this day. Despite the high hopes and aspirations for a cleaner, brighter future as the new millennium began, we find that 14 years into the new century little has been achieved in terms of protecting the climate and the environment in general. It is now a case of 'all hands to the decks', but any international climate treaty that falls short of adhering to principles of 'equity, justice and fairness' is destined to be a fragile affair.

If - as argued here - the onus is on wealthy nations to show leadership on climate change mitigation, it should not be forgotten that no nation is wealthier than the United States of America, at least in terms of GDP, even considering its humungous national debt. According to a report submitted to Congress in August 2013 (http://go.nature.com/311VJE), total US federal climate change expenditure has a budget of US $\$ 21,408$ million for 2014, including US\$2,658 million to fund the US Global Change Research Program and US\$893 million for international assistance; the remainder is accounted for by clean energy technologies (US\$7,933 million), natural resource adaptation (US\$110 million), energy tax provisions that 'may' reduce GHG emissions (US $\$ 5,129$ million) and energy payments in lieu of tax provisions (US $\$ 4,720$ million). This sound like a lot of money, but the figures are paltry compared to what the US spends on defence, for example. According to the Stockholm International Peace Research Initiative (SIPRI), the US spends more on defence than the next eight biggest spenders on defence combined (http://go.nature.com/f68TSF), with total annual spending running into hundreds of billions of dollars. That said, even some eminent former US military leaders now see climate change as a threat to national security (http://go.nature.com/ZAHPng).

The US must now show leadership on climate change - something that President Obama and his administration appear to appreciate. The Star-Spangled Banner, it is said — or rather, sung — "waves o'er the land of the free and the home of the brave." It is one thing to be free, another to be brave; US politicians need courage and determination to decarbonize the economy and to be the standard bearer for global action on climate change. 